\title{
Corporate Social Responsibility Awareness, Firm Commitment and Organizational Performance
}

\author{
Evans Brako Ntiamoah', Priscilla Oforiwaa Egyiri², Michael Kwamega1 \\ ${ }^{1}$ School of Management \& Economics, University of Electronic Science and Technology of China, \\ Chengdu, China \\ ${ }^{2}$ CIM-UK, Simon Page Business School, Accra, Ghana \\ Email: kwamebrako@yahoo.com, Priscilla.Oforiwaa@yahoo.com, kwamegamichael@yahoo.com
}

Received 25 April 2014; revised 27 May 2014; accepted 6 June 2014

Copyright @ 2014 by authors and Scientific Research Publishing Inc.

This work is licensed under the Creative Commons Attribution International License (CC BY).

http://creativecommons.org/licenses/by/4.0/

(c) (i) Open Access

\begin{abstract}
In this research, we addressed the following questions that are becoming increasingly important to managers in the banking industry of Ghana: is there a relationship between corporate social responsibility (CSR) awareness, firm commitment and organizational performance? If yes, how is the relationship between these three variables? The study adopted both qualitative (case study) and quantitative methods respectively. Banks were selected to gather data, which was acquired from answers obtained from our administered questionnaire and also through interviews. The population of the survey constituted the management and non-management staff and customers of UT Bank Ghana and Barclays Bank Ghana Ltd in Ghana. Hypotheses of the study will be analyzed using correlation and regression. Results of the study show that there are high positive correlations between the constructs of corporate social responsibility (CSR) awareness, firm commitment and organizational performance.
\end{abstract}

\section{Keywords}

Corporate Social Responsibility, Firm Commitment, Banking Institution, Organizational Performance

\section{Introduction}

The study was conducted to examine the relationship between corporate social responsibility (CSR) awareness,

How to cite this paper: Ntiamoah, E.B., Egyiri, P.O. and Kwamega, M. (2014) Corporate Social Responsibility Awareness, Firm Commitment and Organizational Performance. Journal of Human Resource and Sustainability Studies, 2, 91-101. http://dx.doi.org/10.4236/jhrss.2014.22008 
firm commitment and organizational performance. In recent times, CSR initiatives have become a priority of the business organizations worldwide in the wake of increasing competition among organizations to win customers through establishing their goodwill in the society by way of undertaking social service activities including donations to charities, community outreach programs, efforts to improve employee diversity, and reducing environmental impact etc. (Bashir et al. [1]). Recent research has shown that the business organizations benefit from CSR activities as well since they enhance their image among their customers and increase their attractiveness to potential and existing employees (Prakash \& Vera-Muñoz [2]).

CSR initiatives have become an integral part of business practice, regardless of the organization's type of markets, and the businesses now allocate hefty amounts in their annual budgets to make what they call it as "investment" in the social service areas (Bashir et al. [1]). A key aspect underlying the debate on corporate social responsibility (CSR) and its impact on organizational performance essentially boils down to what constitutes success for a publicly traded corporation. While profitability has traditionally been regarded as a key metric of a corporation's success, recent views by academics and practitioners suggest that other attributes have come into play. This is evident from a survey of over 1500 corporate leaders at the 2004 World Economic Forum in Davos, Switzerland where less than $20 \%$ of those surveyed attributed profitability to be the most important measure of corporate success while about $25 \%$ indicated that good "corporate citizenship" matters most in defining corporate success. The term corporate citizenship extends to which businesses are socially responsible for meeting legal, ethical and economic responsibilities placed on them by shareholders. The aim is for businesses to create higher standards of living and quality of life in the communities in which they operate, while still preserving profitability for stakeholders.

Academic research on whether CSR is financially beneficial to firms has also burgeoned over the past decade with mixed findings, much like the divergent views of industry participants on the issue. This paper complements and extends this stream of the literature by examining the impact of CSR activities on organizational performance as well as one additional aspect that potentially contributes to corporate success firms' commitment.

The remainder of this paper is structured as follows: Section 2 will present both the theoretical background and hypothesis to this study. Section 3 provides the research methodology of the study. In Section 4, the researchers present the statistical results and discussions of finding. Finally, this study in Section 5 discusses the conclusion of the study.

\section{Theoretical Background and Hypothesis}

\subsection{CSR Awareness and Organizational Performance}

A number of theoretical perspectives have been examined in the literature on the relation between CSR and firm performance. Examples include agency perspective (Levitt [3]; Freidman [4], stakeholder perspective (Freeman [5]; Donaldson and Preston [6]; Jones [7], resource-based view (Wernerfelt [8]; Barney [9]; Hart [10], and slack-resources hypothesis (Waddock and Graves [11]). Agency perspective on CSR argues that absent strong control from shareholders, managers can opportunistically exploit corporate resources to pursue goals that enhance their own utilities at shareholders' costs. Consequently, good social performance comes at the expense of good financial performance because valuable resources are misused to enrich managers instead of being spent on value-added projects or returned to shareholders (Jones [7]).

The stakeholder perspective asserts that firms have relationships with many constituent groups (e.g., customers, employees, and communities) other than just shareholders and that these stakeholders both affect and are affected by the actions of the firm (Freeman [5]). Effective stakeholder management can enhance firms' ability to achieve competitive advantage and long-term value creation. For example, good employee relations might enhance morale, productivity, and satisfaction Moskowitz [12]. Jensen [13] proposes the enlightened value maximization concept, and argues that shareholder value maximization is not incompatible with satisfying certain stakeholders. It utilizes much of the structure of stakeholder theory but emphasizes long-term value maximization as the firm's primary objective. This proposal therefore solves the problems that arise from the multiple objectives that accompany traditional stakeholder theory (e.g., customers want low prices, high quality; employees want high wages and high quality working conditions; suppliers of capital want low risk and high returns; communities want high charitable contributions and social expenditures by firms etc.).

Even though the stakeholder concept has been extensively researched over the past two decades it is frequently defined as the "opposite" to the shareholder (or stockholder) model. The latter states that only the shareholders 
have a legalclaim on the purpose of the firm they own Halal [14]; Emiliani [15]; Mc Adam and Leonard [16]; Weiss [17]. To date, researchers have not come to an agreement on the scope of the stakeholder theory (Harrison and Freeman [18]. Yet, Hillman, Keim and Luce [19] claim that "although a unified stakeholder theory with general acceptance has yet to emerge among stakeholder researchers, there does appear to be some agreement regarding the general concepts embody in the stakeholder theory”. Referring to the work of Jones and Wicks [20] these authors list four main statements at the core of the stakeholder theory: "(1) the firm has relationships with constituent (stakeholder) groups, (2) the processes and outcomes associated with these relationships are of interest, (3) the interests of all legitimate stakeholders have value, (4) the focus of stake holder theory is on managerial decision-making" Hilman et al., [21]. Other stakeholder theorists summarize the two basic principles defining the stakeholder concept as follows: "that to perform well, managers need to pay attention to a wide array of stakeholders, and that managers have obligations to stakeholders which include, but extend beyond, shareholders" Jones et al., [22]. From a rather business-driven perspective, stakeholder theory interest lies in three premises: "organizations have stakeholder groups that affect and are affected by them; these interactions impact on specific stakeholders and the organization; and perspectives of salient stakeholders affect the viability of strategic options" Haberberg and Rieple [23]; Simmons [24].

The resource-based view (RBV) of the firm contends that a firm's ability to perform better than its competitors and create value for shareholders depends on the unique interplay of human, organizational, and physical resources over time. Barney [25] maintains that if these resources meet four criteria: valuable, rare, inimitable, and non-substitutable, they can constitute a source of sustainable competitive advantage. RBV scholars have studied intangibles such as technology, human capital, corporate reputation, and organizational culture. Resources hypothesis Waddock and Graves [26] argues that better firm performance results in a surplus of resources that provides firms with the financial means to address social issues. Waddock and Graves [26] also suggest that CSR and firm performance are synergistic that CSR is both predictor and a consequence of firm performance, thereby forming a virtuous circle. Financially successful companies can afford to spend more money on social issues, but CSR also helps them become financially successful. Just as theoretical predictions on the relation between CSR and firm performance show lack of consensus, results of the empirical studies on the topic are mixed (Berman et al., [27]). In a meta-study on the relation between CSR and firm performance, Margolis and Walsh [28] review 109 studies where CSR has been treated as the independent variable, predicting firm performance. They conclude that out of these 109 studies, 54 showed a positive relationship, 20 showed mixed results, 28 studies reported non-significant relationships, and 7 studies reported a negative relationship. The authors note that possible reasons for the lack of consensus include drawbacks related to measurement issues, and model misspecifications. On the measurement front, the Kinder Lydenberg Domini (KLD) index developed by Kinder, Lydenberg, Domini \& Co., Inc. has been a popular measure for CSR in recent studies (e.g., Graves and Waddock [26] 2000; Waddock and Graves [11]; Berman et al., [27]; McWilliams and Siegel, [29]; Hillman and Keim, [19]; Garcia-Castro et al., [30]; Surroca, Tribo, and Waddock, [31]. KLD rates each company annually on multiple dimensions of social performance. A set of screens are designed to capture how a company is treats its' key stakeholders in the areas of community, corporate governance, diversity, employees, environment, human rights, and product quality. Each of these attributes has strength and concern sub-categories that are rated as either 1 or 0 ( 1 if the company had a strength or concern on a particular issue, and 0 otherwise

Hillman and Keim [19] point out that theoretical work on CSR has yet to identify a ranking of importance for the various stakeholder groups and issues, and thus gives equal importance to the categories adopted from KLD in constructing their CSR measures. Therefore extant studies add up all of the strengths and concerns in each of the categories and construct their CSR measure as the number of strengths of a company minus the number of its concerns. Despite its popularity however, the KLD index suffers from an aggregation problem. For example, by netting the total score on concerns from the strengths' score, a firm with ten strengths and ten concerns across all categories is deemed to have a same level of social responsibility as a firm with one strength and one concern. We argue that this loss in heterogeneity can be mitigated by decomposing the KLD index into its strengths and concerns components Hillman \& Keim, [21]. This disaggregation potentially allows us to reconcile the mixed findings of past studies and distinguish our hypothesis on the CSR-firm performance relation into two separate predictions. Consequently, we hypothesize that:

Hypothesis 1a: The practice of socially responsible activities by firm demonstrates the awareness of CSR demands from its environs. 


\subsection{CSR Activities and Firms Commitment}

Using a theory of the firm perspective, McWilliams and Siegel [29] posit that the primary goal of management in publicly traded firms is to maximize profits/shareholder value. They present a supply/demand framework, in which two companies produce identical products, except that one firm adds an additional "social" attribute to the product to make it more valuable to consumers. In this model, managers conduct a cost-benefit analysis to determine the level of resources to devote to CSR activities. Implications of this model are that (i) CSR can be integral element of firms' differentiation strategies and should be considered as a form of strategic investment, and (ii) RBV logic can be applied to CSR, in the sense that it is possible to generate a set of predictions regarding the patterns of investment in CSR across firms and industries.

Under the McWilliams and Siegel [29] framework, companies' CSR participation is a response to various stakeholders' interests, including demand from consumers, employees, and investors. For instance, investment in CSR can be used as a differentiation strategy, to induce investment in R\&D and greater advertising expenses. On the supply-side, McWilliams and Siegel posit that firms must devote resources to satisfy the demand for CSR. Thus, firms are assumed to use CSR-related capital (land and equipment), labor, materials, and purchased services to generate output. For example, additional commitment and operating expenses could include investment in equipment and facility to reduce pollution, and extra human resource and personnel cost dedicated to CSR program implementation. This leads us to our next hypothesis regarding firm's commitment and CSR.

Hypothesis 1b: The effective implementation of firm's CSR activities demonstrates firm's commitment in attaining CSR goals.

\subsection{CSR Policies and Organizational Performance}

Wartick \& Cochran [32] in their attempt to conceptualize a model for CSR, redefined Carroll's [30] four dimensions of corporate social responsibilities as the "Principles of CSR." Hence, according to Wartick \& Cochran [32], the culture of a company would form the foundation upon which it would formulate and manage its social responsibilities. Borrowing from the works of Freeman and Visser [5], the CSR dimensions and activities most relevant to the business environment in developing countries (Ghana inclusive) relate to the community, the marketplace, the workplace and the environment. Another approach is for companies to issue CSR reports and to assign someone to manage their CSR programme, either in a full-time or a part-time capacity. Again, the models vary widely.

In some companies, CSR officials are full-time high-level executives and the company issues detailed annual CSR reports separate from annual reports. In materializing CSR policies in an organization Pohle \& Hittner [33] suggest the following:

Align and incorporate CSR with business strategy and integrate it across all operational functions. Thus, making it easy to invest (not spend) the funds necessary to achieve the company's objectives, that is both CSR's and the business'.

Implement an open information strategy for more transparent information-sharing with multiple stakeholders.

Leverage transparency to increase the level of engagement of key constituents and customers.

When these activities are done in combination, CSR can become a dimension of a company's successful competitive strategy. Done right, it offers a company improved relationships with all of its key constituents, more loyal customers, lower costs, higher revenues and an overall improvement of the business' standing in society (Pohle \& Hittner [33]).

H2: The practice and implementation of CSR policies and activities are related with the performance of the firm.

\section{Research Methodology}

\subsection{Research Method}

This section provides an overview of the method used for our research and how data for this study were collected and analyzed in order to examine our hypotheses and arrive at the findings. The main objective of this research is to examine the relationship between corporate social responsibility (CSR) awareness, firm commitment and Organizational performance. In order to understand and establish a reliable result we adopted both the use of the qualitative approach and quantitative methods. Quantitative method or approach was adopted because of the 
empirical investigation we conduct into this phenomenon. Data for this section was mainly acquired through the administering of questionnaires to be answered by the firm and its customers. Data obtained from the survey was used to test the hypothesis by SPSS software. In addition, in-depth interviews were used for some questions that investigate how it happened Yin [34]. This qualitative method can throw up important contributions that enrich the real context. In this paper, two firms were chosen as case study. The relevant information was acquired through the field survey such as questionnaires of customers and semi-structured interviews of top managers, and secondary archives from customer complaint forms, the company's corporate social responsibility department as well as other departments.

\subsection{Case Selection}

The process of selecting a suitable case is an essential step to build theories from case studies. This became important because when unsuitable cases are selected, the result obtained will be misleading and will not help us achieve our research objectives. Appropriate selection of case helps define the limit for generalizing the finding of the study and control waste Eisenhardt [35]. Considering the number of cases that can be studied at a particular time choosing a relevant case becomes an essential obligation (Pettigrew [36]).

According to the 2012 Ghana Banking Survey conducted by Price Water House Coopers on behalf of the Ghana Association Bankers, Barclays Bank of Ghana Limited (BBGL), and Unique Trust Bank (UTB) were among the top banks in Ghana ranked by total operating assets, share of industry deposits, net advances, profit margins and representations from their profit and loss statements. The banks were therefore chosen because they represent the top line for Ghanaian banks and they are also comprised of multinational bank (Barclays Bank of Ghana Limited) and the fastest growing indigenous bank (Unique Trust Bank) giving a good local and multinational representation. The selection of the banks also gives representation on listed banks (BBGL and UTB).

\subsection{Data Collection}

The population of the survey constituted the management and non-management staff and customers of UT Bank and Barclays Bank Ltd in Ghana. The researchers used the random sampling technique and accidental technique. The study used a sample size of six hundred and (600) respondents, of which the researchers divided it equally among customers and management staff and non-management staff of both banks. Due to adequate time the researchers devoted for the data collection, the researchers were able to get five hundred and sixty two (562) questionnaires that were administer.

\subsection{Measurement of Variables}

\subsubsection{Corporate Social Responsibility (CSR)}

No single measure or instrument can be used universally to study CSR, Hopkins [37]. For purpose of this research, questions on CSR were asked and placed on a 5-point scale ranging from strongly agree (5), Agree (4), Undecided (3), Disagree (2), and strongly disagree (1) in form of statement. This scale is adopted from Deshpande et al. [38]; Jaworski and Kohli [39]; and Samiee and Roth [40]. The respondents were asked to indicate their level of agreement with each statement in relation to the corporate social responsibility (CSR) of their banking institutions. Item scores were summed and divided by the total number of items so that the composite measure of corporate social responsibility of the banking institutions could be established.

\subsubsection{Firms' Commitment (FC)}

Organizational Commitment Questionnaire was designed to measure participant's commitment to their organizations. All of these questions were measured from "strongly disagree" to "strongly agree". This scale is adopted from Deshpande et al. [38]; Jaworski and Kohli [39]; and Samiee and Roth [40]. The respondents were asked to indicate their level of agreement with these statements in relation the firms' commitment of banking institution.

\subsubsection{Organizational Performance}

For purpose of this research, questions that relate to Organizational performance were asked and placed on a 5point scale ranging from strongly agree (5), Agree (4), Undecided (3), Disagree (2), and strongly disagree (1) in form of statement. This scale is adopted from Deshpande et al. [38]; Jaworski and Kohli [39]; and Samiee and 
Roth [40]. The respondents were asked to indicate their level of agreement with the statements in relation to the Organizational performance of their banking institution by circling the appropriate likert scale. Later, the responses were summed and generalization for the whole banking industry was made.

\subsection{Validity and Reliability of Data}

The reliability of data used for empirical analysis and hypothesis testing was assessed. The reliability of the data was assured by the use of Cronbach's alpha (numerical value of 0.5 is considered appropriate to show consistency). For this research data, the alpha value for corporate social responsibility is 0.69 , firm commitment is 0.59 and organizational performance at 0.74 respectively. The hypothesis formulated for the study was tested by cross-sectional data with the use of statistical software SPSS 20.0. Descriptive statistics and Pearson correlation were generated between variables.

\section{Statistical Results and Discussion}

\subsection{Statistical Population and Statistical Samples}

Statistical population of the study consists of the management and non-management staff and customers of UT Bank and Barclays Bank Ltd in Ghana. 600 questionnaires were administered and 562 of them were used for the analysis. As we can observe from following figures, from 562 respondents, 48 people were with basic education, 177 people were high school graduates, 231 people had completed tertiary education, 106 people had other educational certificates, And this is while the age of 164 of these people were 18 - 24, 256 people between 25 - 34, 60 between 35 - 44, 58 people between 45 - 54 and 24 people were more than 55 years old. Also, among the respondents, 337 people who represent 60 percent were male and 225 who represent 40 percent were female.

\subsection{Corporate Social Responsibility}

This section reports the statistical analysis of our data on corporate social responsibility. Table 1 shows a summary of descriptive statistics and Pearson correlation between all variable used. The dependent variable used is corporate social responsibility awareness (CSRA). The independent variables include does customers demand for a responsible service from firm (CD). Does the firm have CSR policies (CSRP), does the firm provide support for community it's operates (PS), complaints from community about negative impact of firm activities (CCNI).

\subsubsection{Descriptive Statistics}

The Pearson correlation in Table 1 shows that customer complaints have negative impact had the highest correlation coefficient with the dependent variable at 0.94 at $\mathrm{p}<0.01$ (2-tailed) and CSR policies at 0.521 at $\mathrm{p}<$ 0.001 (2-tailed). Also variables such as does customers demand for a responsible service from firm (CD) and does the firm provide support for community it's operates (PS) had a correlation coefficient of 0.724 at $\mathrm{p}<0.01$ (2-tailed), 0.504 at $\mathrm{p}<0.01$ (2-tailed) respectively. Inferences that can be made from this statistical figures above despite they all had a significant correlation with the dependent variable is complaints from community about the negative impact of firm activities is really high. And so in other not for firms to do anything to tarnish their image, the firms have a strong implementation and evaluation plans so they can tackle customers' complaints effectively.

In the study the researchers found out that the respondents were aware of CSR activities by firms. Since the fo-

Table 1. Descriptive statistics and person correlation of corporate social responsibility variable.

\begin{tabular}{ccccccc}
\hline Variables & $\mathrm{N}$ & Mean & SD & 2 & 3 & 5 \\
1. CSRA & 562 & 3.19 & 1.152 & $0.521^{* *}$ & $0.724^{* *}$ & $0.504^{* *}$ \\
2. CSRP & 562 & 3.67 & 1.152 & & $0.690^{* *}$ & $0.939^{* *}$ \\
3. CD & 562 & 3.37 & 1.474 & 0.099 & $0.251^{* *}$ & $0.525^{* *}$ \\
4. PS & 562 & 2.86 & 1.320 & & $0.291^{* *}$ \\
5. CCNI & 562 & 3.47 & 1.038 & & \\
\hline
\end{tabular}

${ }^{* *}$ Correlation is significant at 0.01 level (2-tailed). 
cus was on the extent of the practice of these outlined policies, the findings also showed that the firms do support the communities in devise ways. This finding satisfies the hypothesis (H1a) that states that the practice of socially responsible activities by firm demonstrates the awareness of CSR demands from its environs.

\subsubsection{Regression Analysis}

From Table 2 regression model was established using the equation: $\mathrm{Y}=\alpha+\beta 1 \mathrm{X}_{1}+\beta 2 \mathrm{X}_{2}+\beta 3 \mathrm{X}_{3}+\ldots+\beta \mathrm{nXn}$ where: $\mathrm{Y}$ is the dependent variable, " $\alpha$ " is a regression constant; $\beta 1, \beta 2, \beta 3$ and $\beta \mathrm{n}$ are the beta coefficients; and $\mathrm{X}_{1}, \mathrm{X}_{2}, \mathrm{X}_{3}$, and $\mathrm{Xn}$ are the independent (predicator) variables. Standardized beta coefficients were put in the regression equation. This revealed that corporate social responsibility awareness can be predicated as: $\mathrm{Y}=\alpha+$ $0.69 \mathrm{X}_{1}+0.55 \mathrm{X}_{2}+0.53 \mathrm{X}_{3}+\ldots+\beta \mathrm{nXn}$ where: $Y$ is (CSRA); $\mathrm{X}_{1}$, is (CSRP); $\mathrm{X}_{2}$, is (CD); $\mathrm{X}_{3}$ is (PS), and $\mathrm{Xn}$ is the nth predicator.

\subsection{Firms' Commitment}

FR means does the firm review its policies on CSR, CSRG means CSR goals are communicated clearly among employees, FRT means does the firm responds timely to clients complaints, INF means introducing of innovative-customer friendly products and services, ET means employees trained on the ethics of CSR policies implementation and FC (D) denotes is firm committed to its CSR policies and is the dependent variable.

\subsubsection{Descriptive Statistics}

From Table 3, it shows CSRG, ICF and ET had a significant correlation with the dependent variable at 0.953 at $\mathrm{p}<0.01$ (2-tailed), 0.941 at $\mathrm{p}<0.001$ (2-tailed) and 0.817 at $\mathrm{p}<0.01$ (2-tailed) respectively. Inferences that can be made from this statistical figures above despite they all had a significant correlation with the dependent variable is that the firms does not review their CSR policies on time and responds timely to clients complaints.

The researchers investigated further to know whether these policies were backed with employees' commitment. The finding showed that the firms back their CSR policies with commitment which enables the firm achieves its motives. This finding satisfies our hypothesis (H1b) that states that the effective implementation of firm's CSR activities demonstrates firm's commitment in attaining CSR goals.

\subsubsection{Regression Analysis}

From Table 4, the study also used correlation and regression analysis in testing H1b. The model of analysis was

Table 2. Regression analysis of corporate social responsibility variables.

\begin{tabular}{|c|c|c|c|c|c|c|}
\hline \multirow{2}{*}{ Models } & \multirow{2}{*}{ R-square } & \multicolumn{2}{|c|}{ Unstandardized coefficients } & \multirow{2}{*}{$\begin{array}{c}\text { Standardized coefficient } \\
\text { Beta }\end{array}$} & \multirow{2}{*}{ t-value } & \multirow{2}{*}{ Sig. } \\
\hline & & Beta & Standard Error & & & \\
\hline 1. CSRP & 0.511 & 0.320 & 0.083 & 0.699 & 3.872 & 0.000 \\
\hline 2. CSRP, PS & 0.623 & -0.027 & 0.116 & 0.554 & 3.566 & 0.000 \\
\hline 3. CSRP, PS, CCNI & 0.710 & -0.183 & 0.097 & 0.532 & -2.060 & 0.041 \\
\hline 4. CSRP, PS, CCNI, CD & 0.887 & 0.007 & 0.035 & 0.511 & 3.023 & 0.009 \\
\hline
\end{tabular}

Table 3. Descriptive statistics and person correlation of firms' commitment variable.

\begin{tabular}{|c|c|c|c|c|c|c|c|c|}
\hline Variables & $\mathrm{N}$ & Mean & SD & 2 & 3 & 4 & 5 & 6 \\
\hline 1. FC & 562 & 3.40 & 1.137 & $0.286^{* *}$ & $0.953^{* *}$ & $0.119^{* *}$ & $0.941^{* *}$ & $0.817^{* *}$ \\
\hline 2. FR & 562 & 3.57 & 1.066 & & $0.101^{* *}$ & $0.918^{* *}$ & $0.148^{* *}$ & $0.099^{* *}$ \\
\hline 3. CSRG & 562 & 3.37 & 1.176 & & & $0.227^{* *}$ & $0.955^{* *}$ & $0.843^{* *}$ \\
\hline 4. FRT & 562 & 3.94 & 1.123 & & & & $0.034^{* *}$ & $0.189^{* *}$ \\
\hline 5. ICF & 562 & 3.30 & 1.099 & & & & & $0.875^{* *}$ \\
\hline 6. ET & 562 & 3.28 & 0.918 & & & & & \\
\hline
\end{tabular}

${ }^{* *}$ Correlation is significant at 0.01 level (2-tailed). 
based on the regression analysis: $\mathrm{Y}=\alpha+\beta 1 \mathrm{X}_{4}+\beta 2 \mathrm{X}_{5}+\beta 3 \mathrm{X}_{6}+\ldots+\beta \mathrm{nXn}$ where: $\mathrm{Y}$ is the dependent variable(firm commitment), " $\alpha$ " is a regression constant; $\beta 1, \beta 2, \beta 3$ and $\beta$ n are the beta coefficients and $\left(\mathrm{X}_{4}, \mathrm{X}_{5}\right.$, $\mathrm{X}_{6} \ldots \mathrm{X}_{\mathrm{n}}$ ) are the independent variables. The dependent variable can be predicted as: $\mathrm{Y}=\alpha+0.33 \mathrm{X}_{4}+0.52 \mathrm{X}_{5}$ $+(-1.17) \mathrm{X}_{6}+\ldots+\beta \mathrm{nXn}$ where $\mathrm{X}_{4}, \mathrm{X}_{5}$, and $\mathrm{X}_{6}$ are FR, CSRG and ICF respectively.

\subsection{Organizational Performance}

FG (D) denotes the firms grow since introduction of CSR activities and is the dependent variable; CSRAE means is CSR activities evaluated for shortcomings, CSRAI means is CSR activities implemented timely, IFR means increase in firm's reputation, ICB means increase in customer base, FAAT means the firm always achieves its targets are independent variables.

\subsubsection{Descriptive Statistics}

Table 5 shows that increase in customer base (ICB) had the highest correlation coefficient with the dependent variable at 0.936 at $\mathrm{p}<0.01$ (2-tailed) and is CSR activities evaluated for shortcomings (CSRAE) at 0.865 at $\mathrm{p}<$ 0.01 (2-tailed). Also variables such as increase in firm's reputation and the firm always achieves its targets (FAAT) had a correlation coefficient of 0.907 at $\mathrm{p}<0.01$ (2-tailed), 0.895 at $\mathrm{p}<0.01$ (2-tailed) respectively. Inferences that can be made from this statistical figures above despite they all had a significant correlation with the dependent variable is that firms fails to implement CSR activities on time and it shows that the CSR departments need to do feasibility studies on favorable time before policies are implemented.

The researchers investigated further to know whether these policies have in one way or the other helped the firms' to grow. The findings showed that the firms CSR activities have helped to increase customer base, firms' reputation and the firms always achieve its targets which enable the firms to perform well. This finding satisfies our hypothesis (H2) that states that the practice and implementation of CSR policies and activities are related with the performance of the firm.

\subsubsection{Regression Analysis}

From Table 6, the study also used correlation and regression analysis in testing H2. The model of analysis was based on the regression analysis: $\mathrm{Y}=\alpha+\beta 1 \mathrm{X}_{7}+\beta 2 \mathrm{X}_{8}+\beta 3 \mathrm{X}_{9}+\ldots+\beta \mathrm{nXn}$ where: $\mathrm{Y}$ is the dependent variable

Table 4. Regression analysis of firms’ commitment variables.

\begin{tabular}{|c|c|c|c|c|c|c|}
\hline \multirow{2}{*}{ Model } & \multirow{2}{*}{ R-square } & \multicolumn{2}{|c|}{ Unstandardized coefficients. } & \multirow{2}{*}{$\begin{array}{c}\text { Standardized coefficient } \\
\text { Beta }\end{array}$} & \multirow{2}{*}{ t-value } & \multirow{2}{*}{ Sig. } \\
\hline & & Beta & Standard Error & & & \\
\hline FR & 0.785 & 0.350 & 0.063 & 0.328 & 5.580 & 0.000 \\
\hline FR, CSRG & 0.917 & 0.503 & 0.041 & 0.520 & 12.228 & 0.000 \\
\hline FR, CSRG, ICF & 0.918 & -0.179 & 0.031 & -0.177 & -5.789 & 0.000 \\
\hline FR, CSRG, ICF, FRT & 0.931 & 0.629 & 0.062 & 0.608 & 10.076 & 0.000 \\
\hline FR, CSRG, ICF, FRT, ET & 0.931 & 0.524 & 0.033 & 0.502 & 4.323 & 0.019 \\
\hline
\end{tabular}

Table 5. Descriptive statistics and person correlation of organizational performance variable.

\begin{tabular}{|c|c|c|c|c|c|c|c|c|}
\hline Variables & $\mathrm{N}$ & Mean & $\mathrm{SD}$ & 2 & 3 & 4 & 5 & 6 \\
\hline 1. FG & 562 & 3.40 & 1.160 & $0.865^{* *}$ & $0.099^{* *}$ & $0.907^{* *}$ & $0.895^{* *}$ & $0.936^{* *}$ \\
\hline 2. CSRAE & 562 & 2.94 & 0.870 & & $0.079^{* *}$ & $0.927^{* *}$ & $0.876^{* *}$ & $0.888^{* *}$ \\
\hline 3. CSRAI & 562 & 3.28 & 0.992 & & & $0.203^{* *}$ & $0.106^{* *}$ & $0.277^{* *}$ \\
\hline 4. IFR & 562 & 3.80 & 1.072 & & & & $0.867^{* *}$ & $0.923^{* *}$ \\
\hline 5. FAAT & 562 & 3.09 & 1.092 & & & & & $0.901^{* *}$ \\
\hline 6. ICB & 562 & 3.54 & 1.141 & & & & & \\
\hline
\end{tabular}

${ }^{* *}$ Correlation is significant at 0.01 level (2-tailed). 
Table 6. Regression analysis of organizational performance variables.

\begin{tabular}{|c|c|c|c|c|c|c|}
\hline \multirow{2}{*}{ Model } & \multirow{2}{*}{ R-square } & \multicolumn{2}{|c|}{ Unstandardized coefficients. } & \multirow{2}{*}{$\begin{array}{c}\text { Standarized } \\
\text { coefficient } \\
\text { Beta }\end{array}$} & \multirow{2}{*}{ t-value } & \multirow{2}{*}{ Sig. } \\
\hline & & Beta & Standard Error & & & \\
\hline CSRAE & 0.764 & -0.456 & 0.053 & 0.342 & -8.556 & 0.000 \\
\hline CSRAE, CSRAI & 0.830 & -0.502 & 0.039 & -0.429 & -12.961 & 0.000 \\
\hline CSRAE, CSRAI, IFR & 0.913 & 0.518 & 0.045 & 0.479 & 11.551 & 0.000 \\
\hline CSRAE, CSRAI, IFR, ICB & 0.929 & 0.069 & 0.035 & 0.065 & 1.986 & 0.048 \\
\hline CSRAE, CSRAI, IFR, ICB, FAAT & 0.929 & 0.0 .372 & 0.039 & 0.366 & 9.648 & 0.000 \\
\hline
\end{tabular}

(Organizational Performance), " $\alpha$ " is a regression constant; $\beta 1, \beta 2, \beta 3$ and $\beta$ n are the beta coefficients and $\left(\mathrm{X}_{7}\right.$, $\mathrm{X}_{8}, \mathrm{X}_{9} \ldots \mathrm{X}_{\mathrm{n}}$ ) are the independent variables. The dependent variable can be predicted as: $\mathrm{Y}=\alpha+0.34 \mathrm{X}_{7}+$ $(-0.43) \mathrm{X}_{8}+0.47 \mathrm{X}_{9}+\ldots+\beta \mathrm{nXn}$ where $\mathrm{X}_{7}, \mathrm{X}_{8}$, and $\mathrm{X}_{9}$ are CSRAE, CSRAI and IFR respectively.

\section{Conclusions}

The study was conducted to examine the relationship between corporate social responsibility (CSR) awareness, firm commitment and organizational performance. The study adopted both qualitative (case study) and quantitative methods respectively. Banks were selected to gather data, which was acquired from answers obtained from our administered questionnaire and also through interviews.

The statistical findings showed significantly that the firms are committed in practicing corporate social responsibility. Also there was a significant relationship between corporate social responsibility (CSR) and Organizational performance. The relationship between Firms' commitment and Organizational performance was also positive. The hypothesis established for this study was supported by the researcher findings.

\section{Acknowledgements}

"How good it is to give thanks to you, O Lord, to sing in your honor, O Most High God”. Psalms 92:1. Our thanks go to the Almighty father, the ruler for his protection and guidance over our lives. Our sincerely gratitude also goes to all the staff and management of Unique Trust Bank (Ghana) and Barclays Bank (Ghana) for their assistance and co-operation and not forgetting the respondents who helped us. God richly bless you all.

\section{References}

[1] Bashir, et al. (2011) Impact of Corporate Social Responsibility Activities over the Employees of the Organizations. Journal of Management and Social Sciences, 8, 11-21.

[2] Prakash and Vera-Munoz (2011) Contemporary Issues in Sustainability Accounting, Assurance and Reporting. Valuation Relevance of Environmental Performance, University of Sydney, Sydney.

[3] Levitt, T. (1958) The Dangers of Social Responsibility. Harvard Business Review, 36, 41-50.

[4] Friedman, M. (1970) The Social Responsibility of Business Is to Increase Its Profits. New York Times Magazine, 13 September 1970, 122-126.

[5] Freeman, R.E. (1984) Strategic Management: A Stakeholder Approach. Pitman, Boston.

[6] Donaldson, T. and Preston, L. (1995) The Stakeholder Theory of the Corporation: Concepts, Evidence, and Implications. Academy of Management Review, 20, 65-91.

[7] Jones, R.G., George, M.J. and Hill, W.C. (2000) Contemporary Management. 2nd Edition, McGraw-Hill Companies Inc.

[8] Wernerfelt, B. (1984) A Resource-Based View of the Firm. Strategic Management Journal, 2, 171-180.

[9] Barney, J. (1991) Firm Resources and Sustained Competitive Advantage. Journal of Management, 17, 99-120. http://dx.doi.org/10.1177/014920639101700108

[10] Hart, S.L. (1995) A Natural Resource-Based View of the Firm. Academy of Management Review, 20, 986-1014.

[11] Waddock, S.A. and Graves, S.B. (1997) The Corporate Social Performance Financial Performance Link. Strategic 
Management Journal, 18, 303-319.

http://dx.doi.org/10.1002/(SICI)1097-0266(199704)18:4<303::AID-SMJ869>3.0.CO;2-G

[12] Moskowitz, M. (1972) Choosing Socially Responsible Stocks. Business \& Society Review, 1, 71-75.

[13] Jensen, M.C. (2002) Value Maximization, Stakeholder Theory, and the Corporate Objective Function. Business Ethics Quarterly, 12, 235-256. http://dx.doi.org/10.2307/3857812

[14] Halal, W.E. (2000) Corporate Community: A Theory of the Firm Uniting Profitability and Responsibility. Strategy and Leadership, 28, 2.

[15] Emiliani, M.L. (2001) A Mathematical Logic Approach to the Shareholder vs Stakeholder Debate. Management Decision, 39, 618-622. http://dx.doi.org/10.1108/00251740110399521

[16] McAdam, R. and Leonard, D. (2003) Corporate Social Responsibility in a Total Quality Management Context: Opportunities for Sustainable Growth. Corporate Governance, 3, 36-45. http://dx.doi.org/10.1108/14720700310497104

[17] Weiss, J.W. (2003) Business Ethics: A Stakeholder and Issues Management Approach. South-Western, Thomson Learning, Mason.

[18] Harrison, J.S. and Freeman, R.E. (1999) Stakeholders, Social Responsibility, and Performance: Empirical Evidence and Theoretical Perspectives. Academy of Management Journal, 42, 479-485.

[19] Hillman, A.J., Keim, G.D. and Luce, R.A. (2001) Board Composition and Stakeholder Performance: Do Stakeholder Directors Make a Difference? Business Society, 40, 295-314.

[20] Jones, T. and Wicks, A. (1999) Convergent Stakeholder Theory. Academy of Management Review, 24, $206-221$.

[21] Hillman, A.J. and Keim, G.D. (2001) Shareholder Value, Stakeholder Management, and Social Issues: What's the Bottom Line? Strategic Management Journal, 22, 125-139.

[22] Jones, T.M., Wicks, A.C. and Freeman, R.E. (2002) Stakeholder Theory: The State of the Art. In: Bowie, N.E., Ed., The Blackwell Guide to Business Ethics, Blackwell, Oxford.

[23] Haberberg, A. and Rieple, A. (2001) The Strategic Management of Organisations. Prentice Hall, Harlow.

[24] Simmons, J. (2004) Managing in the Post-Managerialist Era: Towards Socially Responsible Corporate Governance. Management Decision, 42, 601-611. http://dx.doi.org/10.1108/00251740410518985

[25] Barney, J. (2001) Corporate Citizenship and Corporate Social Investment: Drivers of Tri-Sector Partnerships. Journal of Corporate Citizenship, 1, 57-73.

[26] Waddock, S.A. and Boyle, M.E. (1995) The Dynamics of Change in Corporate Community Relations. California Management Review, 37, 125-140. http://dx.doi.org/10.2307/41165814

[27] Berman, S.L., Wicks, A.C., Kotha, S. and Jones, T.M. (1999) Does Stakeholder Orientation Matter? The Relationship between Stakeholder Management Models and the Firm Financial Performance. Academy of Management Journal, 42, 488-506. http://dx.doi.org/10.2307/256972

[28] Margolis, J.D. and Walsh, J.P. (2003) Misery Loves Companies: Rethinking Social Initiatives by Business. Administrative Science Quarterly, 48, 268-305. http://dx.doi.org/10.2307/3556659

[29] McWilliams, A. and Siegel, D. (2000) Corporate Social Responsibility \& Financial Performance: Correlation or Misspecification? Strategic Management Journal, 21, 603-609.

[30] Garcia-Castro, R., Ariño, M.A. and Canela, M.A. (2010) Does Social Performance Really Lead to Financial Performance? Accounting for Endogeneity. Journal of Business Ethics, 92, 107-126. http://dx.doi.org/10.1007/s10551-009-0143-8

[31] Surroca, J., Tribó, J.A. and Waddock, S. (2010) Corporate Responsibility and Financial Performance: The Role of Intangible Resources. Strategic Management Journal, 31, 463-490.

[32] Wartick, S. and Cochran, P. (1985) The Evolution of the Corporate Social Performance Model. Academy of Management Review, 10, 758-769.

[33] Pohle, G. and Hittner, J. (2008) Attaining Sustainable Growth through Corporate Social Responsibility. IBM Global Services.

[34] Yin, R.K. (2009) Case Study Research: Design and Methods. 4th Edition, Sage, Thousand Oaks.

[35] Eisenhardt, K.M. (1989) Building Theories from Case Study Research. The Academy of Management Review, 14, 532550.

[36] Pettigrew, T.F. (1998) Intergroup Contact Theory. Annual Review Psychology, 49, 65-85. http://dx.doi.org/10.1146/annurev.psych.49.1.65

[37] Hopkins, M. (2000) The Measurement of Corporate Social Responsibility. MHC International Ltd., Monthly Feature.

[38] Deshpande, S., Tribo, E. and Waddock, T.A. (2002) Paradoxes and Dilemmas for Stakeholder Responsive Firms in 
Extractive Sector: Lessons from the Case of Shell and the Ogoni. Journal of Business Ethics, 39, 297-318. http://dx.doi.org/10.1023/A:1016542207069

[39] Jaworski, D. and Kohli, A.P. (2008) Corporate Responsibility and Stakeholder Theory. Business Ethics Quarterly, 18, 153-190.

[40] Samiee, R. and Roth, P. (1991) Business Ethics. In: Singer, P., Ed., A Companion of Ethics, Basil Blackwell Limited, Oxford, 354-365. 
Scientific Research Publishing (SCIRP) is one of the largest Open Access journal publishers. It is currently publishing more than 200 open access, online, peer-reviewed journals covering a wide range of academic disciplines. SCIRP serves the worldwide academic communities and contributes to the progress and application of science with its publication.

Other selected journals from SCIRP are listed as below. Submit your manuscript to us via either submit@scirp.org or Online Submission Portal.
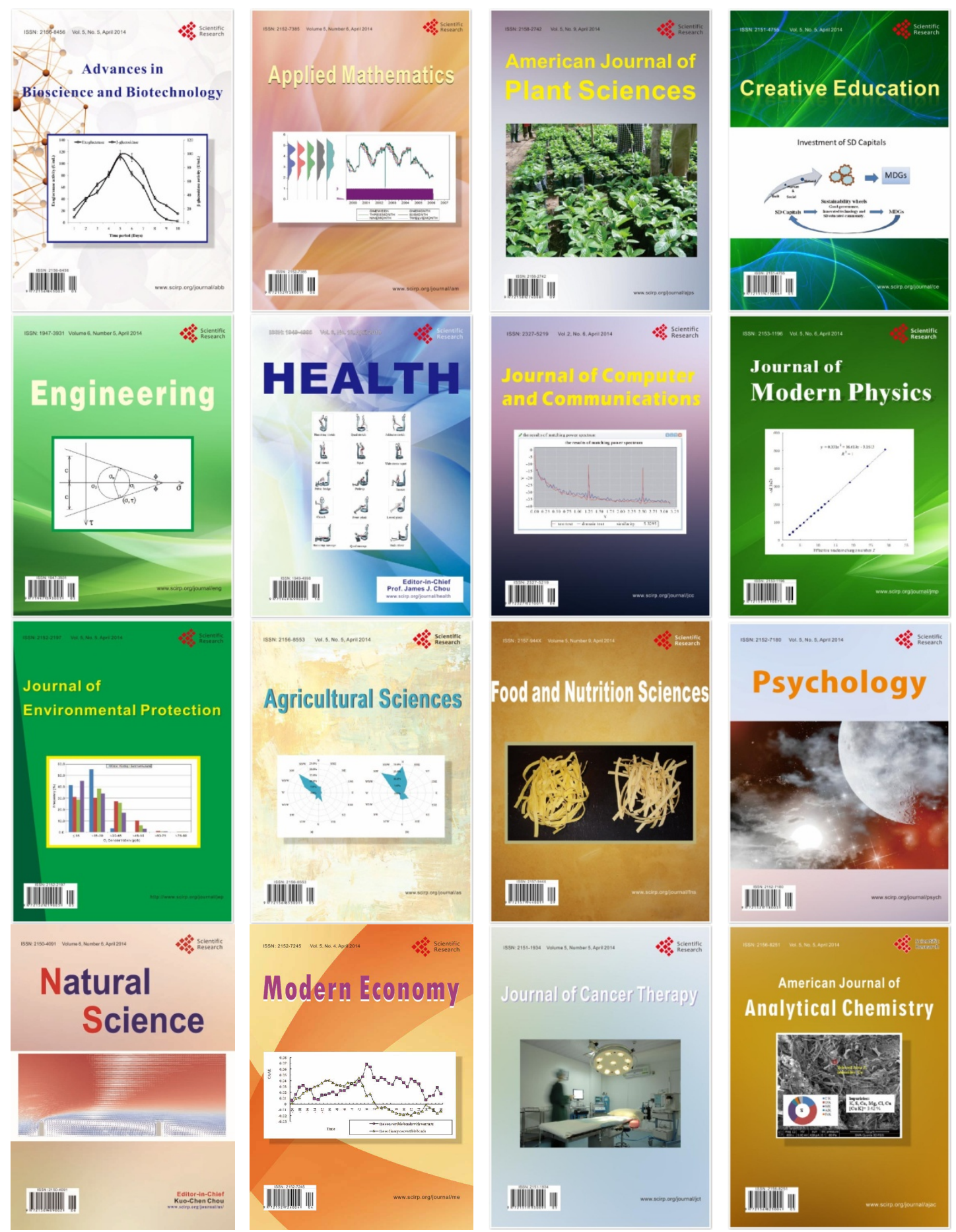